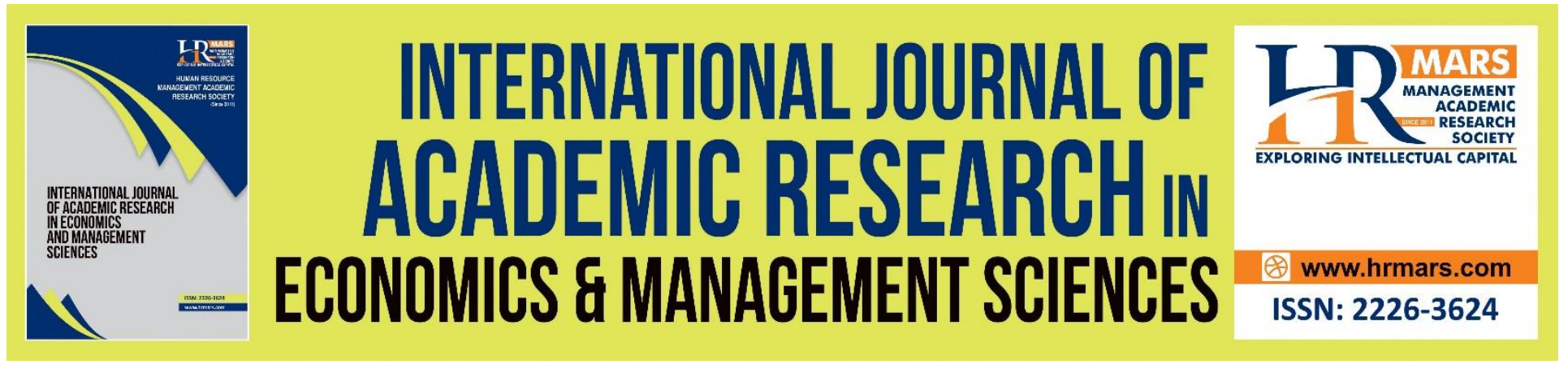

\title{
Survivability of IPO Companies in the Malaysian Market. Evidence from the Kaplan-Meier Survival Analysis
}

Siti Sarah Alyasa-Gan, Norliza Che-Yahya

To Link this Article: http://dx.doi.org/10.6007/IJAREMS/v10-i3/11013 DOI:10.6007/IJAREMS/v10-i3/11013

Received: 05 April 2021, Revised: 27 April 2021, Accepted: 13 May 2021

Published Online: 20 July 2021

In-Text Citation: (Alyasa-Gan \& Che-Yahya, 2021)

To Cite this Article: Alyasa-Gan, S. S., \& Che-Yahya, N. (2021). Survivability of IPO Companies in the Malaysian Market. Evidence from the Kaplan-Meier Survival Analysis. International Journal of Academic Research in Economics and Management and Sciences, 10(3), 192-211.

\section{Copyright: (C) 2021 The Author(s)}

Published by Human Resource Management Academic Research Society (www.hrmars.com)

This article is published under the Creative Commons Attribution (CC BY 4.0) license. Anyone may reproduce, distribute, translate and create derivative works of this article (for both commercial and non-commercial purposes), subject to full attribution to the original publication and authors. The full terms of this license may be seen at: http://creativecommons.org/licences/by/4.0/legalcode

Vol. 10, No. 3, 2021, Pg. 192 - 211

Full Terms \& Conditions of access and use can be found at http://hrmars.com/index.php/pages/detail/publication-ethics 


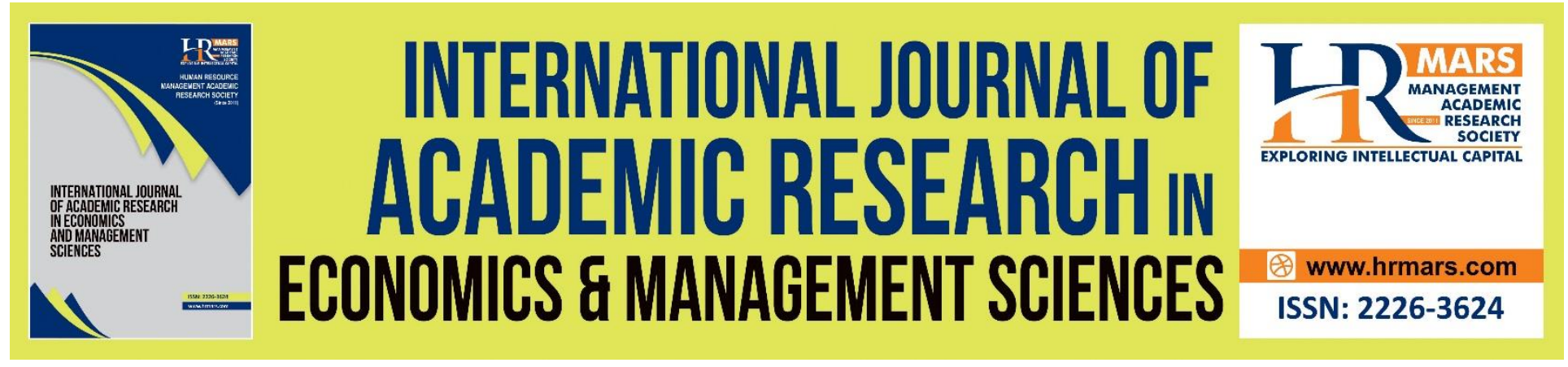

\title{
Survivability of IPO Companies in the Malaysian Market. Evidence from the Kaplan-Meier Survival Analysis
}

\author{
Siti Sarah Alyasa-Gan, Norliza Che-Yahya \\ Faculty of Business and Management, Universiti Teknologi MARA, Puncak Alam, Selangor, \\ Malaysia. \\ Email: norliza9911@uitm.edu.my
}

\begin{abstract}
This study aims to examine the survivability of IPO companies in the Malaysian market. The importance of this study goes consistent with Bursa Malaysia's initiatives in establishing the Practice Notes and Guidance Notes frameworks in elongating the survivability of IPO companies. Responding to the urge, this study examines the survival rate of 527 IPO companies listed in Bursa Malaysia from January 2000 to December 2014 (to observe companies' survival until early August 2021) using the Kaplan-Meier (K-M) survival analysis model. This study reports the survival rate of IPO companies in Malaysia to be at 62.81 percent after five years of listing and 56.91 percent after seven years of listing. Past studies have reported a higher survival rate of IPO companies in the Malaysian market. However, the survival rate of IPO companies should vary according to the definition a study adopts in segregating between surviving and non-surviving companies. Further investigation of the K$M$ log-rank test shows that the survival rate of companies differs according to their listing years, sectors and markets. Comparison between the survival rate of the Main Market and ACE Market reveals that over the seven years post-IPO, companies listed in the Main Market have a 7.55 percent higher survival rate than companies listed in the ACE Market over the seven years of the observation period. As such, it is suggestable that future researchers further examine the contributable factors for IPO companies to survive longer post-IPO using other survival analysis methods (semi-parametric or parametric).
\end{abstract}

Keywords: Initial Public Offerings, Survival, Malaysian Market, Kaplan-Meier, Survival Analysis.

\section{Introduction}

The first and prominent stage of going public is a company's engagement in an initial public offering (IPO). This stage requires the company to issue shares to the general public for the first time (Che-Yahya \& Matsuura, 2021). Apart from fuelling the growth, going public is also one way for a company to convince shareholders of its future survivability in the long-run (Dziczkowski, 2020). The survivability will not only indicate the competitiveness of companies to overcome the brutal market conditions, but it can also signify the ultimate performance of the companies (Baluja \& Singh, 2016). Several reasons can disrupt companies' survivability 
SCIENCES

(C) 2021 HRMARS

which can either be voluntarily reasons (e.g., merger and acquisition, corporate proposal or conversion to a private firm) or involuntarily reasons (inability of fulfilling listing requirements, liquidation or forced liquidation) (Schultz, 1993; Pour \& Lasfer, 2013; Helbing, 2019; Shari, 2019). Despite the grounds on why companies cannot survive longer, the desire to remain viable and sustainable once publicly listed remains the companies' primary goal (Hensler et al., 1997).

IPO companies' survival studies involve the occurrence of any specific event of interest. In other words, it focuses on predicting the companies' long-term survivability with the event occurrence (e.g., delisting of companies or unable to fulfil listing requirements) (Ahmad et al., 2021). It is essential to acknowledge that several different definitions of surviving and nonsurviving companies uniquely suit past studies' scope of the examination. Schultz (1993) and Suárez and Utterback (1995) define surviving companies as companies at their ultimate performance. Schultz (1993) posits that surviving companies should perform substantially to fulfil the listing requirements continuously. The study adds that surviving companies should portray adequate ability to convince investors of their prospects. Hensler et al. (1997) add that the current share should also be at par or higher than their IPO offer price or its first-day market price for the companies to be indicated as surviving companies. Peristiani and Hong (2004) suggest that surviving companies must portray a healthy financial performance (e.g., positive return on assets) as a sign of long-term stability. Apart from maintaining a healthy financial performance, surviving companies should also have adequate ability to withstand the market's competitive nature post-IPO (Lamberto \& Rath, 2010). As an alternative to portray the growth of the companies, Espenlaub et al. (2016) and Shari (2019) mention that surviving companies can also go through market transferring. Simply put, the ultimate performing companies should not be among those that encounter any hiccups ${ }^{1}$ along their journey as listed companies post-IPO. That is, the surviving companies should be rapidly growing regarding their financial credibility and operational activities. Overall, surviving companies could be defined as companies that hold an active status and are at their ultimate performance post-IPO.

The survival of IPO companies carries positive implications because as long as the companies are listed on the Stock Exchange, they can raise capital publicly from the investors. This will enable the companies to finance investment opportunities with high positive net present value and achieve better future success (Andriansyah, 2017). The positive implications of survival extend to other parties such as the investors. Companies that have the capacity to survive longer in the aftermarket will shape a good sentiment from investors as it indicates security for the investors to execute appropriate investments strategies for potential capital appreciation in the long-run (Baluja, 2018). The survival of companies is also crucial to policymakers as they can assess the effectiveness of the rules and guidelines being imposed in the capital market (Gémar et al., 2016). For instance, in the context of the Malaysian market, the initiative of Bursa Malaysia to develop frameworks Practice Note 17 (PN17) and Guidance Note 3 (GN3) to elongate the survival of IPO companies in the Malaysian market shows that companies' survivability carries significant weightage to the policymaker' evaluation for a sustainable capital market. Thus, in view that the survival of IPO companies

\footnotetext{
${ }^{1}$ In the context of this study, hiccups come from several criteria (e.g. insiders possessing lower than 25 percent of companies' equity and companies' subsidiary asset account for 50 percent of the companies' total assets) triggered by companies to be listed or listed in the Practice Note and Guidance Note.
} 
SCIENCES

(C) 2021 HRMARS

is crucial to the companies, investors and Bursa Malaysia, it gives a sudden thrust for this study to be conducted.

It has been distinguished that the survival of IPO companies is a debatable issue, and existing literature reveals that the question of how long companies can survive in the emerging market, specifically in Malaysia, is still scarce. One of the few studies in the Malaysian market by Shari (2019) reports that over five years, the survival of IPO companies is at 92.3 percent and 86.8 percent over seven years. Shari (2019) further elaborated that compared to IPO companies' survival in the developed market, the Malaysian market possesses a better chance of surviving longer post-IPO. Shari (2019) also compared the survival of IPO companies between markets and found that the companies listed in the Main Market have better survivability than the ones listed in the ACE Market. In contrast, a more recent study in the Malaysian market by Ahmad et al. (2021) reports that the survival of IPO companies listed in the ACE Market has a higher rate by 10.4 percent compared to the Main Market throughout three years post-IPO. Ahmad et al. (2021) discover a statistical difference in IPO companies' survival between the Main Market and the ACE Market. Other studies in the developed markets have also found IPO companies' survivability to be statistically different according to companies' listing years and sectors (Espenlaub et al., 2012; Ahmad \& Jelic, 2014; Bhattacharya et al., 2015; Espenlaub et al., 2016). Conforming to the findings in past studies, this study also intends to compare the survival of IPO companies listed in the Main and ACE Market, identifying whether the IPO companies' survival is statistically different between listing years, sectors and markets.

This study contributes to the survival of IPO companies' literature in several ways. Firstly, this study is one of the few studies investigating post-IPO survival of companies in the Malaysian Market. Understanding that studies on IPO companies' survival have only emerged recently, specifically for the Malaysian market, this study intends to address the scarcity by examining more recent IPO companies listed between 2000 and 2014 (traced until 1 August 2021). Secondly, this study investigates the statistical difference of IPO companies' survival by listing years, sectors and markets. Unlike past studies (Espenlaub et al., 2012; Ahmad \& Jelic, 2014; Shari, 2019), who have only found listing years to be statistically different, this study reports that sectors of IPO companies are also highly statistically different for companies' post-IPO survival. In addition, it can act as an additional tool of evaluation or prediction of IPO companies' survivability in the long-run. Thirdly, this study may contribute to several parties, such as the companies to foresee their viability and survivability in achieving their capital motivations and the investors to maximize their wealth through capital appreciation in the long-run. The contribution extends to the policymaker through the alignment of this study's objective and the initiatives of Bursa Malaysia in establishing the Practice Notes and Guidance Notes frameworks, monitoring companies facing financial difficulties and low operating performance to maintain their listing status in Bursa Malaysia.

The rest of this study is organized as follows: Section 2 reviews the past studies on IPO companies' survivability in various markets. Section 3 and 4 describes the data, measurement of IPO companies' survival and methodology employed in this study, respectively. The empirical findings are reported and discussed in Section 5, and Section 6 is the conclusion of this study. 
SCIENCES

(C) 2021 HRMARS

\section{Literature Review}

One of the earliest studies on the survival of companies in the area of the IPO market is by Schultz (1993). Schultz (1993), examining the U.S. market, compares how issuance between unit IPOs ${ }^{2}$ and share IPOs could differ in the companies' ability to survive. From the sample of 797 companies listed from 1986 to 1988, the study reports that the survival rate ranges from 59 percent to 89 percent for companies issuing unit IPOs and share IPOs. Within three years' observation, companies issuing share IPOs report a higher survival rate due to their size. Using a different sample than in Schultz (1993), Hensler et al. (1997) found the survival rate of 741 companies listed in 1975 to 1984 in the U.S. market is at 72 percent after five years of listing. Hensler et al. (1997) found larger companies to have a better survival post-IPO because of the companies' continuous effort to create profits and extensive resources. To add, Kooli and Meknassi (2007) also examine the survival rate of companies in the U.S. market by employing 6,235 companies listed from 1985 to 2005 . The study found that recent companies in the U.S. market five-year survival rate to be lower, at 55 percent.

A study by Jain and Kini (2000), employing 877 companies listed from 1977 to 1990 in the U.S. market, compare the survival rate of venture capitalists (VC) backed companies and nonventure capitalists (NVC) backed companies within five years. The study reports that the survival rate of VC backed companies is higher, at 75 percent, than NVC backed companies at only 70 percent. VC's involvement enhances companies' quality, particularly those producing high technology products, resulting in a higher survival rate. Jain and Kini (2008) rationalize a better chance of companies surviving post-IPO for VC backed companies due to the attention of VCs on the growth of companies that develop complex technologies and emerging products. Hamza and Kooli (2010) also examine the survival rate of VC backed companies. However, the study highlights more on the reputational element of the VCs. Observing three years post-IPO using 6,235 companies listed in 1985 to 2005 in the U.S. market, the study reports a higher survival rate for reputational VC backed companies by 3 percent ( 90 percent and 93 percent) compared to non-reputational VC backed companies. Similar to Hamza and Kooli (2010), Chou et al. (2013) also examine the survival rate of companies backed by reputational VCs using 2,893 companies listed in 1980 to 2003 in the U.S. market. The study reports a similar companies' survival rate to Hamza and Kooli (2010) three years post-IPO at 93 percent. Extending the observation period of companies' survival rate to five years postIPO, Chou et al. (2013) found the survival rate of VC backed companies to be lower, at 87 percent.

As for the U.K. market, 2,499 companies listed in the Main Market from 1975 to 2004 offered a higher survival rate than the Alternative Investment Market (AIM) due to the companies' size differential (Gregory et al., 2010). The study observes the companies' survival rate within five years and reports that Main Market's survival rate is as high as 96 percent compared to 91 percent in the AIM. Since smaller size companies are usually younger, the chance of such companies to survive post-IPO shrinks due to the lack of operating experiences (Chancharat et al., 2012). Conforming that smaller companies are prone to having a lower survival rate, Espenlaub et al. (2012) investigate the survival rate only for companies in the AIM Market. Comparing 896 companies with reputable nominated advisors (NOMAD) and other NOMAD listed in 1995 to 2004 within five years of observation, the study found a significant difference

\footnotetext{
${ }^{2}$ Unit IPOs is a type of IPO issuance consist of bundles of common stocks and warrants which are available in the U.S. stock market (Shari, 2019).
} 
SCIENCES

() 2021 HRMARS

between the two types of companies by 22 percent. The study reports a 70 percent survival rate for reputable NOMAD companies and a 48 percent for other NOMAD companies. A more recent study by Ahmad and Jelic (2014) employing 580 companies listed in 1990 to 2006 in the U.K. market focuses on the voluntary lockup ${ }^{3}$ period that founders extend post-IPO. Regardless of the sample period, the study reports a slightly higher survival rate, at 69 percent than 59 percent for AIM companies, reported in Espenlaub et al (2012) and Vismara et al. (2012) at 57 percent survival rate for European Main Market companies. Ahmad and Jelic (2014) also show that companies with longer lockup periods have a higher survival rate by 5 percent compared to companies with shorter lockup periods.

A recent study in the developing market by Baluja (2018) analyzes how size explains the survival rate of 3,374 companies in the post-SEBI (Securities and Exchange Board of India) era listed in 1992 to 2011. Similar to Schultz (1993); Hensler et al (1997); and Carpentier and Suret (2011), the study reports that out of 50 percent of companies' five-year survival rate, 64 percent are from larger-sized companies. Shari (2019) is the first study (as per the knowledge of this study) that examines the survival rate of companies in Malaysia. Using 352 IPO companies listed from 2002 to 2010, the study reports a slightly lower survival rate of companies at 92 percent after five years of listing than the average survival rate of other AsiaPacific countries at 93 percent reported by Espenlaub et al (2016); Shari (2019) extends the observation period to seven years post-IPO and found the survival rate is lower, at 86 percent, but alternatively higher than the survival rate in other markets. The study reveals that the difference in Malaysian survival rate compared to other markets is due to the uniqueness of the Malaysian market having the frameworks of PN17 and GN3. Another study in the Malaysian market using a more recent sample (2002 to 2017) but a shorter observation period (three years) is by Ahmad et al (2021), reporting that the survival rate of IPO companies is at 83 percent. Table 1 summarizes the survival rate of IPO companies reported in past studies.

\footnotetext{
${ }^{3}$ Lockup is the rule of prevention for IPO companies' founders from selling a whole or a portion of their shares for a specified period post-IPO (Ahmad \& Jelic, 2014). Lockup can be divided into two measures: lockup period or lockup ratio (Che-Yahya \& Abdul-Rahim, 2019).
} 
INTERNATIONAL JOURNAL OF ACADEMIC RESEARCH ECONOMICS AND MANAGEMENT

SCIENCES

(c) 2021 HRMARS

Table 1

Survival Rates of IPO Companies in Various Markets

\begin{tabular}{|l|c|c|c|c|c|c|}
\hline \multirow{2}{*}{ Studies } & Market & \multirow{2}{*}{$\begin{array}{c}\text { Sample } \\
\text { Size }\end{array}$} & Listing Year & \multicolumn{2}{c|}{$\begin{array}{c}\text { Survival Observation } \\
\text { Period \& Rate (\%) }\end{array}$} \\
\cline { 5 - 8 } & & & 3-Years & 5-Years & 7-Years \\
\hline Schultz (1993) & U.S. & 797 & $1986-1988$ & $59-89$ & - & - \\
\hline Hensler et al. (1997) & U.S. & 741 & $1975-1984$ & - & 72 & - \\
\hline Jain and Kini (2000) & U.S. & 877 & $1977-1990$ & - & $70-75$ & - \\
\hline Demers and Joos (2007) & U.S. & 3,574 & $1980-2000$ & - & $83-91$ & - \\
\hline Kooli \& Meknassi (2007) & U.S. & 6,235 & $1985-2005$ & 75 & 55 & - \\
\hline Jain and Kini (2008) & U.S. & 3,837 & $1980-1997$ & - & 66 & - \\
\hline Bhattacharya et al. (2009) & U.S. & 356 & $1982-2000$ & - & $76-86$ & - \\
\hline Hamza and Kooli (2010) & U.S. & 6,235 & $1985-2005$ & $90-93$ & - & - \\
\hline Chou et al. (2013) & U.S. & 2,893 & $1980-2003$ & 93 & 87 & - \\
\hline Gregory et al. (2010) & U.K. & 2,499 & $1975-2004$ & - & $91-96$ & - \\
\hline Espenlaub et al. (2012) & U.K. & 896 & $1995-2004$ & 74 & 59 & - \\
\hline Ahmad and Jelic (2014) & U.K. & 580 & $1990-2006$ & 84 & 69 & - \\
\hline $\begin{array}{l}\text { Carpentier and Suret } \\
\text { (2011) }\end{array}$ & Canada & 2,373 & $1986-2003$ & - & 88 & - \\
\hline Chancharat et al. (2012) & Australia & 125 & $1994-2002$ & - & 74 & - \\
\hline Baluja (2018) & India & 3,374 & $1992-2011$ & - & 50 & - \\
\hline Shari (2019) & Malaysia & 352 & $2002-2010$ & - & 92 & 87 \\
\hline Ahmad et al. (2021) & Malaysia & 332 & $2002-2017$ & 83 & - & - \\
\hline Vismara et al. (2012) & $\begin{array}{l}\text { 4 Europe } \\
\text { Countries }\end{array}$ & 3,755 & $1995-2009$ & - & 58 & - \\
\hline Espenlaub et al. (2016) & 32 Countries & 7,627 & $2000-2008$ & 89 & 78 & - \\
\hline
\end{tabular}

\section{Methodology}

\section{Data and Sampla Description}

This study uses secondary data of 527 companies listed in the Main Market ${ }^{4}$ (364 IPO companies) and the ACE Market (163 IPO companies) of Bursa Malaysia from January 2000 to August 2014. This study ends its sample period in August 2014 to cater to the seven-year observation of companies' survival until early August 2021 (the latest observation period this study can cover). The data on companies' endpoint of survival, listing date, sectors and markets are all quantitatively hand-collected from the companies' prospectuses and Bursa Malaysia's website. Acknowledging the common definition of surviving companies in past studies, this study regards surviving companies as companies with active status and at their ultimate performance (i.e., continuously fulfilling the listing requirements as public companies) (Schultz, 1993; Hensler et al., 1997; Peristiani \& Hong, 2004; Lamberto \& Rath, 2010; Espenlaub et al., 2012) and non-surviving companies, otherwise. This study uses STATA Release 17 software to develop the statistical inference. Following Shari (2019), this study observes companies' survivability over seven years, from the IPO companies' listing date to the end of survival observation this study covers (1 August 2021).

\footnotetext{
${ }^{4}$ Since Main Market is the merger between the Main Board and Second Board, IPO Companies listed in 2000 and 2001 under the Main Board and Second Board are included as the Main Market sample.
} 
SCIENCES

(C) 2021 HRMARS

\section{Measurement of IPO Companies' Survival}

The IPO companies' survival is the companies' time-to-survive, which is the duration from companies' listing date until the end time that the companies have survived, expressed in months (Espenlaub et al., 2012; Neneh \& Smit, 2014; Pour, 2015; Pommet, 2017). According to Hensler et al. (1997), the estimation of companies' survival is often right-censored, which means that the endpoint of the survival is unobserved (covers only until the end of the observation period). As the survival analysis model includes the observation of censored data, using a binary variable is also necessary to denote whether an observation is a censored observation or not. Thus, in measuring the IPO companies' survival, this study requires to include not only the companies' time-to-survive but also the binary variable ("1" or "0"). The steps to estimate companies' survival period are shown below.

Step 1: Estimate the survival.

$S_{i}=t_{1 i}-t_{0 i}$

where $\left(S_{i}\right)$ is the company's survival, $\left(t_{1 i}\right)$ is the endpoint of a company's survival and $\left(t_{o i}\right)$ is the company's listing date.

Step 2: After identifying the company's survival (in months), the estimation continues with the denotation of the censored observation.

$$
\begin{aligned}
D_{\text {Survive }_{i}=I F} \mid \text { Censored } & =" 1 " \mid \\
\mid \text { Non-Censored } & =" 0 " \mid
\end{aligned}
$$

where ( $\left.D^{\text {Survive }}\right)$ is the censored data of the company using dummy survive.

\section{Survival Analysis Model}

The survival rate of the sample in the dataset, which includes the censored observation (rightcensored), can be measured non-parametrically (non-normality of data) by adopting the Kaplan-Meier (K-M) survival analysis model. Ahmad and Jelic (2014) suggest that the nonparametric survival analysis model can be employed to examine the statistical difference between the companies' survivability rate of each sub-sampling attribute over a specified period. This study intends to test the difference in companies' survival rates according to the listing years, sectors and full sample of companies. The K-M survival analysis model is a preferred test to measure companies' survival rate, as it holds no assumption on the normality of data. This study adopts the K-M log-rank test to test whether there are statistical differences in the survival rate between the sub-sampling attributes (listing years, sectors and full sample) for seven years post-IPO. Figure 1 illustrates the K-M log-rank test of this study, and the K-M model can be expressed as follows:

$S\left(t_{i}\right)=S\left(t_{i-1}\right)\left(\frac{n_{i}-d_{i}}{n_{i}}\right)$

where $S\left(t_{i}\right)$ is the probability of surviving in month $t_{i}, S\left(t_{i-1}\right)$ is the probability of surviving in month $t_{i-1}, n_{i}$ is the sample size at the month beginning $t_{i}, d_{i}$ is the number of sample nonsurviving at the month $\mathrm{t}_{i}$. Figure 1 illustrates the $\mathrm{K}-\mathrm{M}$ log-rank test for this study. 
SCIENCES

(C) 2021 HRMARS

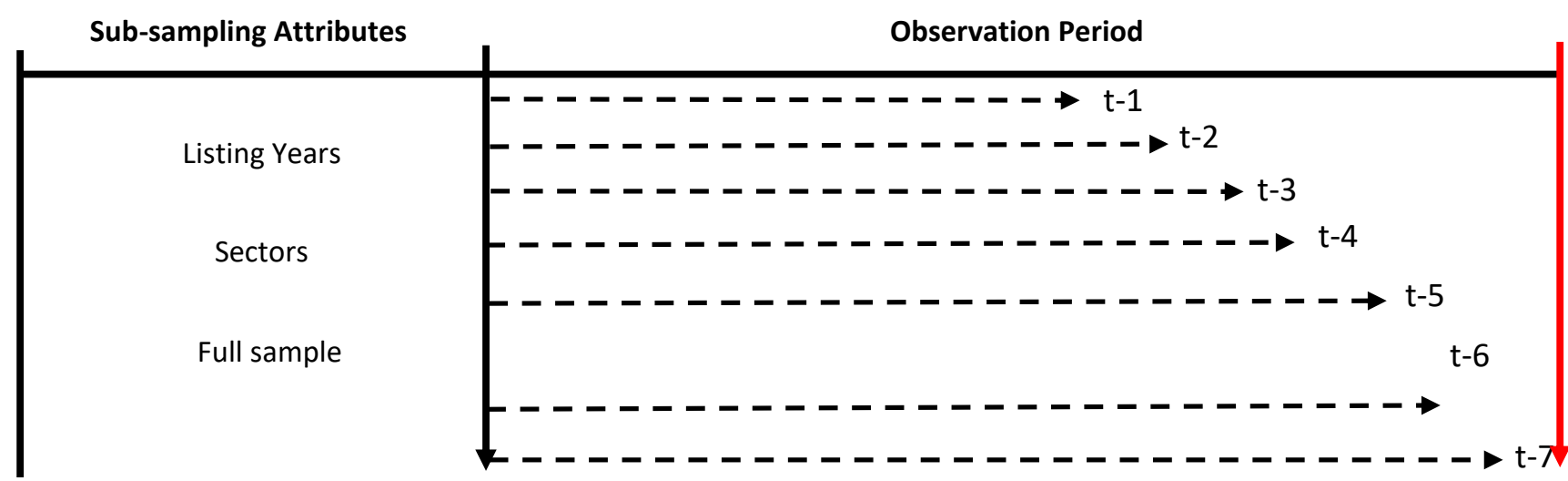

Beginning of observation

End of observation

( $1^{\text {st }}$ trading day)

( $1^{\text {st }}$ August 2021)

Figure 1: Illustration of Kaplan-Meier Log-Rank Test

\section{Results and Discussions}

\section{IPO Companies' Survival Rates and Longevity}

Table 2 presents the survival rates of IPO companies over the observation period of seven years between listing years (Panel A), sectors (Panel B) and full sample (Panel C). The survival rates across listing years and sectors can be seen to vary considerably. This study measures using the non-parametric survival analysis method, the Kaplan-Meier (K-M) model. Referring to Panel A of Table 2, the K-M log-rank test shows that the survival rates of IPO companies across listing years are statistically different at $1 \%$ significant level with a chi-square value of 45.27. Further, it reports a substantial variation in the IPO companies' median survival time (ranging from 6 months to 162 months). The results portray that out of fifteen years of listing, none of the IPO companies listed in 2001, 2009, 2012 and 2013 face difficulties fulfilling the listing requirements and maintaining their listing status after one year of being publicly listed companies (100\% survival rate). Similar to the findings in Shari (2019), IPO companies listed in 2009 have the highest survival rate among the fifteen years of listing, with $92.86 \%$ of companies at their ultimate performance throughout the seven years of observation period (minimum median at 151 months). This study analyzes that 2009 was the third and last phase of implementing the Capital Market Masterplan $1^{5}$. The Securities Commission Malaysia further strengthened the market processes in becoming a fully developed and international capital market, leading the IPO companies listed to survive longer post-IPO. To add, IPO companies listed from 2009 to 2014 have among the highest survival rate from the first year of trading ( $92.86 \%$ to $100 \%)$ to the end of seven years post-IPO (71.43\% to $92.86 \%)$. More than $50 \%$ of the IPO companies listed from 2009 to 2014 can survive ultimately seven years post-IPO.

It is also worth highlighting that from 2000 to 2014, the highest number of IPO companies entering the capital market is in 2005. Although 51.9\% of the IPO companies in 2005 may be ultimately surviving companies up until the third year of listing, the statistic shows that IPO companies listed in 2005 are continuously facing challenges to survive until the sixth and seventh year of listing, at $37.97 \%$ survival rate (lowest after listing year 2006). Considering the

\footnotetext{
${ }^{5}$ Capital Market Master Plan 1 is the Malaysian government initiatives in strengthening and broadening Malaysia's capital market for a more strategic future direction starting 2001 to 2010. This initiative was established and executed by the Securities Commission of Malaysia (SCM).
} 
SCIENCES

(c) 2021 HRMARS

challenges, it only takes 40 months for half of the IPO companies to fall short in continuously trading post-IPO. According to Baluja and Singh (2016), periods of high IPO activity levels attract more companies with lower quality to enter the market for their opportunistic advantages. This phenomenon is indicated as the "hot issue phenomenon". Accordingly, IPO companies listed in a hot issue period perform well in a shorter period and have a relatively lower chance of surviving longer post-IPO (Hensler et al., 1997; Ljungqvist et al., 2006; Kooli \& Meknassi, 2007; Espenlaub et al., 2016). Another interesting finding to highlight is that IPO companies listed in 2008 have the greatest difficulties in surviving as public listed companies even after the first year of listing. The majority of the IPO companies (more than 50\%) in 2008 have been either delisted, unable to fulfil the listing requirements or merged after the first year of listing. It is explainable as 2008 is when the Global Financial Crisis takes place, and many companies (private and public) felt the impact of economic and financial instability (Ali \& Hatta, 2013). It only takes 6 months for half of the IPO companies in 2008 to be nonsurviving companies. However, the impact of the Global Financial Crisis is only applicable to some companies listed in 2008 , as the remaining $43.48 \%$ surviving companies can survive ultimately until the end of seven years of observation post-IPO.

The survival rates of IPO companies in the Malaysian market also vary across sectors. As indicated in Panel B of Table 2, the K-M log rank-rank test shows that there are statistical differences of IPO companies' survival rates across sectors at $1 \%$ significant level with a chisquare value of 93.90. A substantial degree of variation in the IPO companies' median survival time is also demonstrated, ranging from 33 months to 160 months. Interestingly, all IPO companies in seven out of fifteen sectors (closed end fund, financial services, healthcare, infrastructure projects, Special Purpose Acquisition (SPAC), telecommunications and media, and utilities) are surviving companies for two consecutive years post-IPO, at $100 \%$ survival rate. IPO companies in closed end funds, telecommunication and media, and utilities possess the highest survival rates in the third, fifth and seventh year at $100 \%$ post-IPO. Understanding that there is only one or two IPO companies listed in the three sectors with the highest survival rate, the $100 \%$ survival rate exhibit that all of the IPO companies listed in the three sectors can continuously trade at their ultimate performance until the end of the seven years observation post-IPO. In contrast, the only IPO company listed in the transportation and logistics sector struggles to maintain its listing status even before achieving its first year of listing.

To add, IPO companies listed in the financial services sector have among the highest survivability with a survival rate of $90 \%$ in third-year post-IPO and experience a slight decrease of survival rate by $10 \%$ (90\% to $80 \%$ ) in the fourth year post-IPO while sustaining and surviving ultimately until the end of the seven years' observation period. This study also reports that it takes 111 months for $50 \%$ of IPO companies in the financial services sector to be non-surviving companies, which is relatively an extended period for the majority of the IPO companies to survive post-IPO. This finding is consistent with Lamberto and Rath (2010) reporting that IPO companies classified in the financial services sector are more likely to survive longer than IPO companies in other sectors. Understanding that the financial services sector provides the capital and liquidity in the market, the financial services sector should remain as one of the strong sectors for a sustainable capital market (SCM, 2001). Another sector worth giving attention to is the plantation sector, whereby the IPO companies' survival rate is the secondhighest in the first and second year post-IPO at $91.67 \%$. Although there is a decrement in the 
SCIENCES

(c) 2021 HRMARS

third year by $16.67 \%$ (91.67\% to $75 \%$ ) in the third year post-IPO, the remaining surviving IPO companies can ultimately survive until the end of the seven-year observation. To highlight, the plantation sector has the highest survival time median (excluding the N/A) at 160 months for $50 \%$ of the IPO companies to experience shortcomings throughout the seven years of listing. According to Shari (2019), the plantation sector was heavily supported by the Malaysian government through the Ninth Malaysia Plan ${ }^{6}$, allocating RM11.4 billion to develop the plantation sector. Similarly, the study also found that it is justifiable that IPO companies in the plantation sector face lesser difficulties through the Malaysian government's support, enabling the IPO companies to survive longer post-IPO.

Observable in Panel B of Table 2, the infrastructure projects sectors encounter a substantial decrease in survival rate from $100 \%$ in the first two consecutive years post-IPO to $25 \%$ until the seventh year of listing (three out of four companies become non-survivors). This makes the sector with the lowest survival rate for five consecutive years. The survival time median indicated that $50 \%$ of the IPO companies in the infrastructure project sector experience the shortest time in becoming non-surviving companies compared to other sectors, at 33 months. Furthermore, it can be analyzed that two out of four IPO companies listed in the SPAC sector experienced a shortfall in the third year post-IPO, leaving the other two IPO companies to survive ultimately until the end of seven years post-IPO. The 36 month of survival time median is going according to the listing requirement stated by the SCM in the 4th Revision Equity Guidelines Chapter 6. IPO companies listed as SPAC will only be given 36 months to execute their plan acquiring assets (SCM, 2021). Given that the IPO companies failed to adhere to the listing requirement, such IPO companies will no longer trade in the capital market, explaining that the two IPO companies cannot survive longer than 36 months post-IPO. Next, the technology sector portrays the lowest survival rate at $68.32 \%$ in the second year of listing and the second-lowest from the third to the seventh year, ranging from $44.51 \%$ to $51.49 \%$. IPO companies listed in the technology sector have always been indicated as higher risk IPO companies because of the rapid and technological changes the sector encounters (Wyatt, 2014). The risk of IPO companies listed in the technology sector revolves around market acceptance. If investors turn against certain products, the IPO companies might face issues sustaining profit and growth (Demer \& Joos, 2007; Bhattacharya et al., 2009). As a result of the inadequate resources, $50 \%$ of the IPO companies could only survive as long as 50 months post-IPO.

In an overall outlook, Panel C reports the full sample survival rate of IPO companies listed from 2000 to 2014 regardless of sectors. The survival rate reports that out of 527 IPO companies, $16.13 \%$ of IPO companies have difficulties surviving in the first year of listing. Only $83.87 \%$ of IPO companies remain as surviving companies in the first year post-IPO. In the third-year post-IPO, the survival rate of IPO companies plunges by another $12.33 \%(83.87 \%$ to $71.54 \%)$. This study reports lower survival rates than found in past studies, both developed and developing markets (Schultz, 1993; Kooli \& Meknassi, 2007; Chou et al., 2013; Ahmad \& Jelic, 2014; Shari, 2019; Ahmad et al., 2021). Consistently, the survival rate falls lower in the fifth year post-IPO, at $62.81 \%$ and seventh year post-IPO, at $56.91 \%$. This finding is substantially lower than the average survival rate of IPO companies in the Asia-Pacific

\footnotetext{
${ }^{6}$ The Ninth Malaysia Plan is the Malaysian National Development agenda aim to achieve a more value-added and stronger economy within the period of 2006 to 2010. The Ninth Malaysia Plan emphasizes in narrowing the gap between the development of the rural and urban areas in Malaysia (Economic Planning Unit, 2006).
} 
SCIENCES

(c) 2021 HRMARS

reported in a study by Espenlaub et al. (2016), at 96.84\% three years after listing and $93.17 \%$ five years after listing. This study also emphasizes that the IPO companies' survival rate is significantly lower than the survival rate of IPO companies reported in the two studies conducted (Shari, 2019 and Ahmad et al., 2021) in the Malaysian market throughout the seven years observation. The finding reports a median of 114 months for the remaining $50 \%$ of IPO companies to survive post-IPO. To justify, the definition of surviving companies in both studies conducted in the Malaysian market is not similar to that of surviving companies applies in this study, i.e., actively traded IPO companies at their ultimate performance. Thus, the variation in the survival rate of IPO companies reported in all studies should vary according to the definition of surviving companies each study uniquely adopts.

\section{IPO Companies' Survival Rates by Listing Markets}

Table 3 presents the survival rates of IPO companies by listing markets over the observation period of seven years between listing years (Panel A), sectors (Panel B) and full sample (Panel $C)$. The survival rates across listing years and sectors can be seen to vary considerably. Similar to Table 2, this study measures using the non-parametric survival analysis method, the Kaplan-Meier (K-M) model. Referring to Panel A of Table 3, the K-M log-rank test shows that the survival rates of IPO companies across listing years are statistically different at 5\% significant level for ACE Market and 1\% significant level for Main Market with a chi-square value of 21.68 and 32.27. It indicates a higher variation of survival rates across listing years for IPO companies listed in the Main Market compared to the ACE Market. In comparison, out of fifteen listing years, a majority of IPO companies are listed in the Main Market compared to ACE Market, which is in 2002, 2003, 2004, 2007, 2008, 2009, 2010, 2011, 2012, 2013 and 2014, suggesting that most IPO companies listed in the Malaysian market are large-sized companies. Although most IPO companies are listed in the Main Market, IPO companies listed in the ACE Market demonstrate a higher survival rate for eight listing years $(2002,2003,2004$, $2008,2009,2010,2012,2013$ and 2014) out of the thirteen listing years. The IPO companies' survival rates listed in the eight listing years range from $54.84 \%$ to $100 \%$, while those listed in the Main Market range from $45.45 \%$ to $91.67 \%$ over the seven years of observation. It is also worth noting that IPO companies listed in 2009 have the highest survival rates regardless of markets. Both ACE and Main Market IPO companies majorly survive from the first year postIPO until the seventh year post-IPO, ranging from $91.67 \%$ to $100 \%$. It is consistent with what has been reported in Panel A for Table 2, whereby 2009 is the listing year with most IPO companies that can survive ultimately post-IPO throughout the seven years post-IPO.

In contrast, IPO companies listed in 2005 and 2006 have among the lowest survival rates for ACE (27.27\% and $32.61 \%$ ) and Main Market (44.44\% and $45.45 \%$ ) throughout the seven years observation period. In 2005, although more than $50 \%$ of IPO companies can survive in the first two years post-IPO for the ACE Market, the remaining IPO companies are consistently facing difficulties in surviving as public listed companies from the third to the seventh year post-IPO (47.83\% to $32.61 \%)$. It is also observable that 2005 has the highest number of IPO companies for the ACE Market, further proving that host-issue periods IPO companies will less likely survive longer post-IPO. In parallel motion, the listing year 2006 reports only $45.45 \%$ of survival rate for IPO companies listed in the ACE Market with continuous decline until the fifth-year post-IPO, at $27.27 \%$ and remain similar until the seventh-year observation period. On the other hand, only 50\% of IPO companies listed in the Main Market remain as surviving companies after the fourth-year post-IPO and slightly decrease by $5.56 \%$, at $44.44 \%$ in the 
Table 2

Companies' Survival Rates Post-IPO

\begin{tabular}{|c|c|c|c|c|c|c|c|c|c|c|}
\hline \multirow{2}{*}{ Categories } & \multirow{2}{*}{$\begin{array}{c}\text { No. of } \\
\text { Compa } \\
\text { nies }\end{array}$} & \multicolumn{7}{|c|}{ Cumulative Survival Rates (\%) } & \multirow{2}{*}{\begin{tabular}{|c|}
$\begin{array}{c}\text { ST } \\
\text { (Months) } \\
50 \%\end{array}$ \\
\end{tabular}} & \multirow{2}{*}{$\begin{array}{c}\text { Log } \\
\text { Rank } \\
\text { Test } \\
\end{array}$} \\
\hline & & \multicolumn{3}{|c|}{\begin{tabular}{|l|l|l|} 
Year 1 & Year 2 & Year 3 \\
\end{tabular}} & \multicolumn{4}{|c|}{ 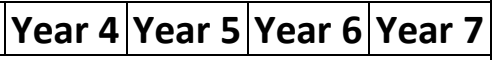 } & & \\
\hline \multicolumn{9}{|l|}{$\begin{array}{l}\text { Panel A: Listing } \\
\text { Years }\end{array}$} & & \\
\hline 2000 & 38 & 97.37 & 94.74 & 92.11 & 86.84 & 81.58 & 78.95 & 73.68 & 162 & \multirow{15}{*}{$\begin{array}{c}\text { Chi- } \\
\text { Square } \\
= \\
45.27^{* *} \\
*\end{array}$} \\
\hline 2001 & 20 & 100.00 & 95.00 & 90.00 & 70.00 & 70.00 & 65.00 & 65.00 & 131 & \\
\hline 2002 & 51 & 94.12 & 86.27 & 80.39 & 70.59 & 64.71 & 56.86 & 50.98 & 91 & \\
\hline 2003 & 58 & 79.31 & 74.14 & 68.97 & 62.07 & 55.17 & 55.17 & 53.45 & 95 & \\
\hline 2004 & 72 & 90.28 & 75.00 & 70.83 & 59.72 & 59.72 & 56.94 & 54.17 & 102 & \\
\hline 2005 & 79 & 74.68 & 60.76 & 51.90 & 46.84 & 43.04 & 37.97 & 37.97 & 40 & \\
\hline 2006 & 40 & 65.00 & 52.50 & 47.50 & 40.00 & 35.00 & 35.00 & 35.00 & 31 & \\
\hline 2007 & 26 & 61.54 & 61.54 & 57.69 & 57.69 & 57.69 & 57.69 & 53.85 & 94 & \\
\hline 2008 & 23 & 43.48 & 43.48 & 43.48 & 43.48 & 43.48 & 43.48 & 43.48 & 6 & \\
\hline 2009 & 14 & \multicolumn{3}{|c|}{100.00100 .00100 .00} & 100.00 & 100.00 & 100.00 & 92.86 & (151) & \\
\hline 2010 & 29 & 93.10 & 89.66 & 82.76 & 82.76 & 79.31 & 79.31 & 79.31 & (139) & \\
\hline 2011 & 28 & 92.86 & 92.86 & 92.86 & 92.86 & 92.86 & 89.29 & 71.43 & $(127)$ & \\
\hline 2012 & 18 & 100.00 & 94.44 & 88.89 & 88.89 & 88.89 & 88.89 & 88.89 & (115) & \\
\hline 2013 & 17 & 100.00 & 100.00 & 88.24 & 88.24 & 82.35 & 76.47 & 76.47 & $(103)$ & \\
\hline 2014 & 14 & 92.86 & 92.86 & 85.71 & 85.71 & 85.71 & 71.43 & 71.43 & $(91)$ & \\
\hline \multicolumn{9}{|l|}{ Panel B: Sectors } & & \\
\hline Closed End Fund & 1 & 100.00 & 100.00 & 100.00 & 100.00 & 100.00 & 100.00 & 100.00 & $\mathrm{~N} / \mathrm{A}$ & \multirow{12}{*}{$\begin{array}{c}\text { Chi- } \\
\text { Square } \\
= \\
93.90^{* *} \\
*\end{array}$} \\
\hline Construction & 12 & 83.33 & 83.33 & 83.33 & 66.67 & 66.67 & 66.67 & 50.00 & 79 & \\
\hline $\begin{array}{l}\text { Consumer Products } \\
\text { \& Services }\end{array}$ & 78 & 88.46 & 84.62 & 79.49 & 74.36 & 71.79 & 65.38 & 62.79 & 122 & \\
\hline Financial Services & 10 & 100.00 & 100.00 & 90.00 & 80.00 & 80.00 & 80.00 & 80.00 & 111 & \\
\hline Healthcare & 2 & 100.00 & 100.00 & 100.00 & 50.00 & 50.00 & 50.00 & 50.00 & 43 & \\
\hline $\begin{array}{l}\text { Industrial Products \& } \\
\text { Services }\end{array}$ & 141 & 81.56 & 76.60 & 74.47 & 68.09 & 63.12 & 59.57 & 58.16 & 123 & \\
\hline $\begin{array}{l}\text { Infrastructure } \\
\text { Projects }\end{array}$ & 4 & 100.00 & 100.00 & 25.00 & 25.00 & 25.00 & 25.00 & 25.00 & 33 & \\
\hline Plantation & 12 & 91.67 & 91.67 & 75.00 & 75.00 & 75.00 & 75.00 & 75.00 & 160 & \\
\hline Property & 23 & 91.30 & 78.26 & 78.26 & 73.91 & 73.91 & 73.91 & 69.57 & 142 & \\
\hline $\begin{array}{l}\text { Real Estate } \\
\text { Investment Trusts }\end{array}$ & 15 & 66.67 & 60.00 & 60.00 & 60.00 & 60.00 & 60.00 & 60.00 & N/A & \\
\hline $\begin{array}{l}\text { Special Purpose } \\
\text { Acquisition }\end{array}$ & 4 & 100.00 & 100.00 & 50.00 & 50.00 & 50.00 & 50.00 & 50.00 & 36 & \\
\hline Technology & 101 & 83.17 & 68.32 & 59.41 & 51.49 & 48.51 & 46.53 & 44.51 & 50 & \\
\hline
\end{tabular}


INTERNATIONAL JOURNAL OF ACADEMIC RESEARCH ECONOMICS AND MANAGEMENT SCIENCES Vol. 10, No. 3, 2020, E-ISSN: 2226-3624 @ 2020 HRMARS

\begin{tabular}{|l|c|c|c|c|c|c|c|c|c|c|}
\hline $\begin{array}{l}\text { Telecommunications } \\
\text { \& Media }\end{array}$ & 2 & 100.00 & 100.00 & 100.00 & 100.00 & 100.00 & 100.00 & 100.00 & 102 & \\
\hline Trading Services & 120 & 81.67 & 74.17 & 71.67 & 68.33 & 65.00 & 61.67 & 56.64 & 128 \\
\hline $\begin{array}{l}\text { Transportation \& } \\
\text { Logistics }\end{array}$ & 1 & 0.00 & 0.00 & 0.00 & 0.00 & 0.00 & 0.00 & 0.00 & N/A \\
\hline Utilities & 1 & 100.00 & 100.00 & 100.00 & 100.00 & 100.00 & 100.00 & 100.00 & N/A & \\
\hline Panel C: Full Sample \\
\hline \multicolumn{7}{|l|}{} \\
\hline Total & 527 & 83.87 & 76.66 & 71.54 & 65.84 & 62.81 & 59.77 & 56.91 & 114 & \\
\hline
\end{tabular}

Notes: This table shows the cumulative survival rates of IPO companies listed from 2000 to 2014 using the Kaplan-Meier survival analysis model for seven years of observation. Panel A reports the survival rates of IPO companies across listing years, Panel B across sectors and Panel $\mathrm{C}$ is the full sample of IPO companies included in this study (527 IPO companies). This table reports the survival time (ST) median in months. Following Espenlaub et al. (2012), this study uses $50 \%$ for the ST to show how long (in months) the companies fall below $50 \%$ post-IPO. In Panel A, any value in the parentheses indicates the minimum ST, i.e., the remaining time from the IPO companies' listing year to the end of this study's observation period (August 2021). Any value of (N/A) reported in Panel $B$ is due to the cumulative survival rates being greater than $50 \%$ up to the end of the observation period (seven years post-IPO). This table also reports the significance of the statistical difference between the survival rates across IPO companies' listing years and sectors using the Kaplan-Meier log-rank test. Significant levels at 1\%, 5\%, 10\% denote as ***,**, *, respectively.

fifth-year post-IPO. The figure remains similar until the seventh-year post-IPO. In sum, IPO companies

listed in 2006 have the lowest survival rate across the listing years for both markets. Referring to Panel B in Table 3, the survival rates of IPO companies across sectors are only statistically different and significant for Main Market at 1\% significant level with a chi-square value of 69.56. The sectors difference in survival rates for ACE Market is statistically insignificant with a chisquare value of 2.44 , demonstrating lesser variation for all six sectors (ranging between $44.63 \%$ and $100 \%$ ). Focusing on the survival rates across sectors for IPO companies listed in the Main Market, closed end fund, telecommunication and media, and utilities sectors are found to have a consistent $100 \%$ survival rate from the first year of trading until the seventh year of trading. It indicates that all three IPO companies listed in the three sectors can survive ultimately post-IPO. To add, consumer products and services, industrial products and services, and trading services sectors in the Main Market possess the highest number of IPO companies compared to the ACE Market. It signifies that IPO companies listed in the three sectors are majorly large-sized companies. More than $50 \%$ of IPO companies remain as surviving companies throughout the seven-year observation period post-IPO (ranges from $56.30 \%$ to $60.61 \%$ ).

Moving on to the infrastructure project sector, where the IPO companies are collectively surviving companies up to the second year post-IPO at $100 \%$ survival rate, none of the IPO companies remains as surviving companies starting from the third year until the end of the seventh year post-IPO. Similar to the finding for sectors in Table 2, IPO companies listed in the technology sector have one of the lowest survival rates at $33.33 \%$ throughout the seven years of 
observation period. Although fewer companies are listed in the technology sector for the Main Market (6 IPO companies compared to 94 IPO companies in the ACE Market), more than $50 \%$ of the IPO companies failed to survive at their ultimate performance after five years of listing. Consistent with the finding in Table 2 for the transportation and logistics sector, the only IPO company listed in the sector cannot maintain as surviving companies lesser than a year of being a public listed company. Overall, Panel $\mathrm{C}$ reports that the cumulative survival rates for IPO companies listed in the Main Market compared to ACE Market are consistently higher, except for the first year of trading post-IPO, at $57.83 \%$ and $50.28 \%$ after seven years of listing.

\section{Summary and Conclusion}

This paper examines the survivability of IPO companies listed from 2000 to 2014 in the Malaysian market. Given that survivability can be measured using the survival analysis method, this study employs the Kaplan-Meier model to estimate IPO companies' survival rate and longevity in the Malaysian market. Compared to past studies (Shari, 2019; Ahmad et al., 2021), this study reports a lower IPO companies' survival rate over the seven years observation period using the sample of IPO companies in the Malaysian market. To the extent that the definition of surviving companies is dissimilar in each study, the survival rate for the IPO companies should vary accordingly. This study finds a survival time median of 114 months for IPO companies listed in the Malaysian market. Both the listing years and sectors are significantly different for the survival rates. Comparison of the survival rate for IPO companies listed between the Main Market and ACE Market reports that only survival rates across listing years are significantly different for both markets. Survival rates across sectors are only significant for the IPO companies listed in the Main Market. Collectively, IPO companies listed in the Main Market have a higher survival rate compared to ACE Market at the end of the observation period. 
INTERNATIONAL JOURNAL OF ACADEMIC RESEARCH ECONOMICS AND MANAGEMENT SCIENCES Vol. 10, No. 3, 2020, E-ISSN: 2226-3624 @ 2020 HRMARS

\section{Table 3}

Companies' Survival Rates Post-IPO by Listing Markets

\begin{tabular}{|c|c|c|c|c|c|c|c|c|c|c|c|c|c|c|c|c|c|c|}
\hline \multirow[t]{2}{*}{ Categories } & \multirow[t]{2}{*}{$\begin{array}{c}\mathrm{Ob} \\
\mathrm{s.}\end{array}$} & \multicolumn{7}{|c|}{$\begin{array}{l}\text { ACE Market Cumulative } \\
\text { Survival Rates (\%) }\end{array}$} & \multirow{2}{*}{$\begin{array}{c}\text { Log } \\
\text { Ran } \\
\text { k } \\
\text { Tes } \\
\text { t } \\
\end{array}$} & & \multicolumn{7}{|c|}{$\begin{array}{c}\text { Main Market Cumulative } \\
\text { Survival Rates (\%) }\end{array}$} & \multirow{2}{*}{$\begin{array}{c}\text { Log } \\
\text { Ran } \\
\text { k } \\
\text { Tes } \\
\text { t } \\
\end{array}$} \\
\hline & & $\begin{array}{l}\text { Yea } \\
\text { r } 1\end{array}$ & $\left|\begin{array}{l}\text { Yea } \\
\text { r } 2\end{array}\right|$ & $\left|\begin{array}{l}Y e a \\
r 3\end{array}\right|$ & Yea & $\begin{array}{l}Y e a \\
\text { r } 5\end{array}$ & $\begin{array}{l}\text { Yea } \\
\text { r } 6\end{array}$ & $\begin{array}{l}\text { Yea } \\
\mathrm{r} 7\end{array}$ & & & $\begin{array}{c}\text { Yea } \\
\text { r } 1\end{array}$ & $\begin{array}{l}\text { Yea } \\
\text { r }\end{array}$ & $\begin{array}{l}Y e a \\
r 3\end{array}$ & $\begin{array}{l}Y e a \\
r 4\end{array}$ & $\begin{array}{l}\text { Yea } \\
\text { r } 5\end{array}$ & $\begin{array}{l}\text { Yea } \\
\text { r } 6\end{array}$ & $\begin{array}{l}\text { Yea } \\
\text { r } 7\end{array}$ & \\
\hline $\begin{array}{l}\text { Panel A: Listing } \\
\text { Years }\end{array}$ & & & & & & & & & & & & & & & & & & \\
\hline 2002 & 7 & $\begin{array}{l}100 \\
.00 \\
\end{array}$ & $\begin{array}{l}100 \\
.00 \\
\end{array}$ & $\begin{array}{l}100 \\
.00 \\
\end{array}$ & $\begin{array}{l}100 \\
.00 \\
\end{array}$ & $\begin{array}{l}85 . \\
71\end{array}$ & $\begin{array}{l}85 . \\
71 \\
\end{array}$ & $\begin{array}{c}85.7 \\
1\end{array}$ & & 44 & $\begin{array}{c}93 . \\
18 \\
\end{array}$ & $\begin{array}{l}84 . \\
09 \\
\end{array}$ & $\begin{array}{l}77 . \\
27\end{array}$ & $\begin{array}{c}65 . \\
91 \\
\end{array}$ & $\begin{array}{l}61 . \\
36\end{array}$ & & $\begin{array}{c}45.4 \\
5\end{array}$ & \\
\hline 2003 & 20 & $\begin{array}{l}100 \\
.00\end{array}$ & $\begin{array}{l}95 . \\
00\end{array}$ & $\begin{array}{c}90 . \\
00\end{array}$ & $\begin{array}{l}75 . \\
00\end{array}$ & $\begin{array}{c}65 . \\
00\end{array}$ & $\begin{array}{l}65 . \\
00 \\
\end{array}$ & $\begin{array}{c}65.0 \\
0\end{array}$ & & 38 & $\begin{array}{l}68 . \\
42 \\
\end{array}$ & $\begin{array}{l}63 . \\
16\end{array}$ & $\begin{array}{l}57 . \\
89\end{array}$ & $\begin{array}{l}55 . \\
26\end{array}$ & $\begin{array}{l}50 . \\
00\end{array}$ & $\begin{array}{l}50.4 \\
00\end{array}$ & $\begin{array}{c}47.3 \\
7 \\
\end{array}$ & \\
\hline 2004 & 31 & & $\begin{array}{l}74 . \\
19 \\
\end{array}$ & $\begin{array}{r}64 . \\
52 \\
\end{array}$ & $\begin{array}{l}58 . \\
06 \\
\end{array}$ & $\begin{array}{l}58 . \\
06\end{array}$ & $\begin{array}{l}58 . \\
06 \\
\end{array}$ & $\begin{array}{c}54.8 \\
4\end{array}$ & & 41 & \begin{tabular}{|c|}
85 \\
37 \\
\end{tabular} & $\begin{array}{l}75 . \\
61 \\
\end{array}$ & $\begin{array}{l}75 . \\
61 \\
\end{array}$ & $\begin{array}{l}60 . \\
98 \\
\end{array}$ & $\begin{array}{l}60 . \\
98 \\
\end{array}$ & $\begin{array}{l}56.5 \\
10 \\
\end{array}$ & $\begin{array}{c}53.6 \\
6 \\
\end{array}$ & \\
\hline 2005 & 46 & & $\begin{array}{l}58 . \\
70\end{array}$ & $\begin{array}{l}47 . \\
83\end{array}$ & $\begin{array}{l}39 . \\
13 \\
\end{array}$ & $\begin{array}{l}36 \\
96\end{array}$ & $\begin{array}{l}32 . \\
61 \\
\end{array}$ & $\begin{array}{c}32.6 \\
1\end{array}$ & & 33 & $\begin{array}{l}69 . \\
70 \\
\end{array}$ & $\begin{array}{l}63 . \\
64\end{array}$ & $\begin{array}{l}57 . \\
58\end{array}$ & $\begin{array}{l}57 . \\
58\end{array}$ & $\begin{array}{l}51 . \\
52\end{array}$ & & $\begin{array}{c}45.4 \\
5\end{array}$ & \\
\hline 2006 & 22 & & $\begin{array}{l}45 \\
45\end{array}$ & $\begin{array}{l}36 \\
36 \\
\end{array}$ & $\begin{array}{l}31 . \\
82 \\
\end{array}$ & & \begin{tabular}{|l|}
27. \\
27 \\
\end{tabular} & $\begin{array}{c}27.2 \\
7\end{array}$ & & 18 & $\begin{array}{l}66 . \\
67 \\
\end{array}$ & $\begin{array}{l}61 . \\
11 \\
\end{array}$ & $\begin{array}{l}61 . \\
11 \\
\end{array}$ & $\begin{array}{l}50 . \\
00 \\
\end{array}$ & $\begin{array}{l}44 . \\
44 \\
\end{array}$ & & $\begin{array}{c}44.4 \\
4 \\
\end{array}$ & \\
\hline 2007 & 3 & & $\begin{array}{r}33 . \\
33 \\
\end{array}$ & $\begin{array}{l}33 . \\
33\end{array}$ & $\begin{array}{r}33 . \\
33\end{array}$ & $\begin{array}{r}33 . \\
33\end{array}$ & $\begin{array}{l}33 . \\
33\end{array}$ & $\begin{array}{c}33.3 \\
3\end{array}$ & & 23 & $\begin{array}{l}65 . \\
22 \\
\end{array}$ & $\begin{array}{l}65 . \\
22\end{array}$ & $\begin{array}{l}60 . \\
87\end{array}$ & $\begin{array}{l}60 . \\
87\end{array}$ & $\begin{array}{l}60 . \\
87\end{array}$ & & & \\
\hline 2008 & 8 & & $\begin{array}{l}50 . \\
00\end{array}$ & $\begin{array}{l}50 \\
00\end{array}$ & $\begin{array}{l}50 . \\
00\end{array}$ & $\begin{array}{l}50 . \\
00\end{array}$ & $\begin{array}{l}50 . \\
00\end{array}$ & $\begin{array}{c}50.0 \\
0\end{array}$ & & 15 & $\begin{array}{l}40 . \\
00\end{array}$ & $\begin{array}{l}40 . \\
00\end{array}$ & $\begin{array}{l}40 . \\
00\end{array}$ & $\begin{array}{l}40 . \\
00\end{array}$ & $\begin{array}{l}40 . \\
00 \\
\end{array}$ & & & \\
\hline 2009 & 2 & $\begin{array}{l}100 \\
.00\end{array}$ & 100 & $\begin{array}{l}100 \\
.00\end{array}$ & $\begin{array}{l}100 \\
.00\end{array}$ & $\begin{array}{l}100 \\
.00\end{array}$ & $\begin{array}{l}100 \\
.00\end{array}$ & 100. & $* *$ & 12 & $\begin{array}{r}100 \\
.00\end{array}$ & $\begin{array}{l}100 \\
.00\end{array}$ & $\begin{array}{l}100 \\
.00\end{array}$ & 100 & $\begin{array}{l}100 \\
.00\end{array}$ & & $\begin{array}{c}91.6 \\
7\end{array}$ & \\
\hline 2010 & 6 & & $\begin{array}{r}83 . \\
33\end{array}$ & $\begin{array}{c}83 . \\
33\end{array}$ & $\begin{array}{c}83 . \\
33\end{array}$ & $\begin{array}{c}83 . \\
33\end{array}$ & $\begin{array}{l}83 . \\
33\end{array}$ & $\begin{array}{c}83.3 \\
3\end{array}$ & & 23 & $\begin{array}{l}95 . \\
65 \\
\end{array}$ & $\begin{array}{l}91 . \\
30\end{array}$ & $\begin{array}{l}82 . \\
61 \\
\end{array}$ & $\begin{array}{l}82 . \\
61 \\
\end{array}$ & $\begin{array}{l}78 . \\
26 \\
\end{array}$ & $\begin{array}{l}78.7 \\
26\end{array}$ & $\begin{array}{c}78.2 \\
6 \\
\end{array}$ & \\
\hline 2011 & 11 & $\begin{array}{l}81 . \\
82 \\
\end{array}$ & $\begin{array}{l}81 . \\
82\end{array}$ & \begin{tabular}{|l|}
81. \\
82 \\
\end{tabular} & \begin{tabular}{|l|}
81. \\
82
\end{tabular} & $\begin{array}{l}81 . \\
82\end{array}$ & \begin{tabular}{|l|}
81. \\
82 \\
\end{tabular} & $\begin{array}{c}63.6 \\
4\end{array}$ & & 17 & $\begin{array}{r}100 \\
.00 \\
\end{array}$ & $\begin{array}{l}100 \\
.00 \\
\end{array}$ & $\begin{array}{l}100 \\
.00 \\
\end{array}$ & $\begin{array}{l}100 \\
.00\end{array}$ & $\begin{array}{l}100 \\
.00 \\
\end{array}$ & $\begin{array}{l}94.7 \\
12\end{array}$ & \begin{tabular}{|c|}
76.4 \\
7 \\
\end{tabular} & \\
\hline 2012 & 3 & $\begin{array}{l}100 \\
.00 \\
\end{array}$ & $\begin{array}{l}100 \\
.00\end{array}$ & $\begin{array}{l}100 \\
.00\end{array}$ & $\begin{array}{l}100 \\
.00\end{array}$ & $\begin{array}{l}100 \\
.00\end{array}$ & & $\begin{array}{c}100 . \\
00\end{array}$ & & 15 & $\begin{array}{l}100 \\
.00\end{array}$ & $\begin{array}{l}93 . \\
33\end{array}$ & $\begin{array}{l}86 . \\
67\end{array}$ & $\begin{array}{l}86 . \\
67 \\
\end{array}$ & $\begin{array}{l}86 . \\
67 \\
\end{array}$ & $\begin{array}{l}86.8 \\
67\end{array}$ & $\begin{array}{c}86.6 \\
7 \\
\end{array}$ & \\
\hline 2013 & 1 & $\begin{array}{l}100 \\
.00 \\
\end{array}$ & $\begin{array}{l}100 \\
.00\end{array}$ & $\begin{array}{l}100 \\
.00\end{array}$ & $\begin{array}{l}100 \\
.00\end{array}$ & $\begin{array}{l}100 \\
.00\end{array}$ & $\begin{array}{l}100 \\
.00 \\
\end{array}$ & $\begin{array}{l}100 . \\
00\end{array}$ & & 16 & $\begin{array}{l}100 \\
.00\end{array}$ & $\begin{array}{l}100 \\
.00 \\
\end{array}$ & $\begin{array}{l}87 . \\
50\end{array}$ & $\begin{array}{l}87 . \\
50 \\
\end{array}$ & $\begin{array}{l}81 . \\
25 \\
\end{array}$ & $\begin{array}{l}75 . \\
00\end{array}$ & $\begin{array}{c}75.0 \\
0 \\
\end{array}$ & \\
\hline 2014 & 3 & $\begin{array}{l}100 \\
.00 \\
\end{array}$ & 100 & $\begin{array}{l}100 \\
.00\end{array}$ & $\begin{array}{l}100 \\
.00\end{array}$ & $\begin{array}{l}100 \\
.00\end{array}$ & $\begin{array}{l}66 . \\
67\end{array}$ & $\begin{array}{c}66.6 \\
7\end{array}$ & & 11 & $\begin{array}{l}90 . \\
91\end{array}$ & $\begin{array}{l}90 . \\
91\end{array}$ & $\begin{array}{l}81 . \\
82\end{array}$ & $\begin{array}{l}81 . \\
82\end{array}$ & $\begin{array}{l}81 . \\
82\end{array}$ & $\begin{array}{l}72.7 \\
73\end{array}$ & $\begin{array}{c}72.7 \\
3\end{array}$ & \\
\hline $\begin{array}{l}\text { Panel B: } \\
\text { Sectors }\end{array}$ & & & & & & & & & & & & & & & & & & \\
\hline $\begin{array}{l}\text { Closed End } \\
\text { Fund }\end{array}$ & $\begin{array}{l}\mathrm{N} / \\
\mathrm{A}\end{array}$ & $\begin{array}{l}\mathrm{N} / \\
\mathrm{A}\end{array}$ & $\begin{array}{c}N / \\
A\end{array} \mid$ & $\begin{array}{c}N / \\
A\end{array} \mid$ & $\begin{array}{c}\mathrm{N} / \\
\mathrm{A}\end{array} \mid$ & $\mid \begin{array}{c}\mathrm{N} / \\
\mathrm{A}\end{array}$ & N/ & & & & $\begin{array}{l}100 \\
.00\end{array}$ & $\begin{array}{l}100 \\
.00 \\
\end{array}$ & $\begin{array}{l}100 \\
.00\end{array}$ & $\begin{array}{l}100 \\
.00\end{array}$ & $\begin{array}{l}100 \\
.00\end{array}$ & $\begin{array}{l}1001 \\
.00\end{array}$ & $\begin{array}{l}100 . \\
00\end{array}$ & $\begin{array}{l}\text { Chi- } \\
\text { Squ }\end{array}$ \\
\hline
\end{tabular}


INTERNATIONAL JOURNAL OF ACADEMIC RESEARCH ECONOMICS AND MANAGEMENT SCIENCES Vol. 10, No. 3, 2020, E-ISSN: 2226-3624 @ 2020 HRMARS

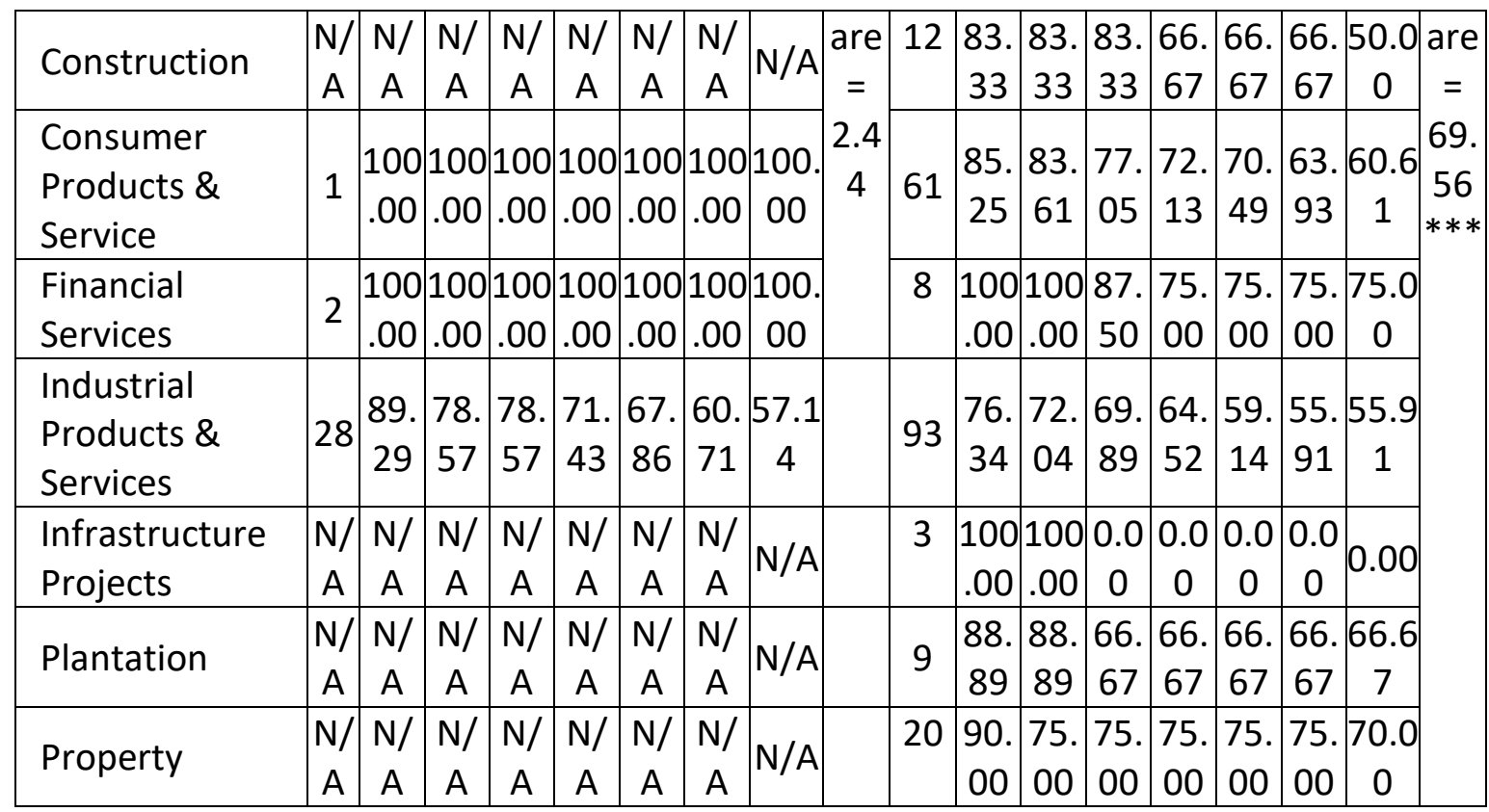

\begin{tabular}{|c|c|c|c|c|c|c|c|c|c|c|c|c|c|c|c|c|}
\hline $\begin{array}{l}\text { Real Estate } \\
\text { Investment } \\
\text { Trusts }\end{array}$ & $\begin{array}{l}\mathrm{N} / \\
\mathrm{A}\end{array}$ & $\begin{array}{c}N / \\
A\end{array}$ & $\begin{array}{c}N \\
A\end{array}$ & N/ & $\begin{array}{c}N / \\
A\end{array}$ & $\begin{array}{c}N \\
A\end{array} \mid$ & $\begin{array}{c}\text { N/ } \\
A\end{array}$ & $\begin{array}{c}\text { N/ } \\
A\end{array}$ & 15 & $\begin{array}{c}66 . \\
67\end{array}$ & $\begin{array}{l}60 . \\
00\end{array}$ & $\begin{array}{l}60 . \\
00\end{array}$ & $\begin{array}{l}60 . \\
00\end{array}$ & $\begin{array}{l}60 . \\
00\end{array}$ & $\begin{array}{l}60 . \\
00\end{array}$ & $\begin{array}{l}60 . \\
00\end{array}$ \\
\hline $\begin{array}{l}\text { Special } \\
\text { Purpose } \\
\text { Acquisition }\end{array}$ & $\begin{array}{c}\mathrm{N} / \\
\mathrm{A}\end{array}$ & $\begin{array}{l}\text { N/ } \\
A\end{array}$ & $\begin{array}{c}N \\
A\end{array}$ & N/ & $\begin{array}{c}N / \\
A\end{array}$ & $\begin{array}{c}\mathrm{N} / \\
\mathrm{A}\end{array}$ & $\begin{array}{c}\mathrm{N} / \\
\mathrm{A}\end{array}$ & $\begin{array}{c}\text { N/ } \\
A\end{array}$ & 4 & $\begin{array}{c}10 \\
0.0 \\
0\end{array}$ & $\begin{array}{c}10 \\
0.0 \\
0\end{array}$ & $\begin{array}{l}50 . \\
00\end{array}$ & $\begin{array}{l}50 . \\
00\end{array}$ & & $\begin{array}{l}50 . \\
00\end{array}$ & $\begin{array}{l}50 . \\
00\end{array}$ \\
\hline Technology & 94 & $\begin{array}{l}82 . \\
98\end{array}$ & $\begin{array}{l}68 . \\
09\end{array}$ & $\begin{array}{l}58 . \\
51\end{array}$ & $\begin{array}{l}51 . \\
06\end{array}$ & $\begin{array}{l}47 . \\
87\end{array}$ & $\begin{array}{l}46 . \\
81\end{array}$ & $\begin{array}{l}44 . \\
63\end{array}$ & 6 & $\begin{array}{l}83 . \\
33\end{array}$ & $\begin{array}{l}66 . \\
67\end{array}$ & $\begin{array}{l}66 . \\
67\end{array}$ & $\begin{array}{l}50 . \\
00\end{array}$ & $\begin{array}{l}50 . \\
00\end{array}$ & $\begin{array}{l}33 . \\
33\end{array}$ & $\begin{array}{l}33 . \\
33\end{array}$ \\
\hline $\begin{array}{l}\text { Telecommuni } \\
\text { cation \& }\end{array}$ & 1 & $\begin{array}{l}10 \\
0.0\end{array}$ & $\begin{array}{l}10 \\
0.0\end{array}$ & $\begin{array}{l}10 \\
0.0\end{array}$ & $\begin{array}{l}10 \\
0.0\end{array}$ & $\begin{array}{l}10 \\
0.0\end{array}$ & $\begin{array}{l}10 \\
0.0\end{array}$ & 100 & 1 & $\begin{array}{l}10 \\
0.0\end{array}$ & $\begin{array}{l}10 \\
0.0\end{array}$ & $\begin{array}{l}10 \\
0.0\end{array}$ & $\begin{array}{l}10 \\
0.0\end{array}$ & $\begin{array}{l}10 \\
0.0\end{array} \mid$ & $\begin{array}{l}10 \\
0.0\end{array}$ & $\begin{array}{c}100 \\
00\end{array}$ \\
\hline Media & & 0 & 0 & 0 & 0 & 0 & 0 & .00 & & 0 & 0 & 0 & 0 & 0 & 0 & \\
\hline $\begin{array}{l}\text { Trading } \\
\text { Services }\end{array}$ & 37 & $\begin{array}{l}75 . \\
68\end{array}$ & $\begin{array}{l}64 . \\
86\end{array}$ & $\begin{array}{l}59 . \\
46\end{array}$ & $\begin{array}{l}56 . \\
76\end{array}$ & $\begin{array}{l}54 . \\
05\end{array}$ & $\begin{array}{l}54 . \\
05\end{array}$ & $\begin{array}{l}54 . \\
05\end{array}$ & 71 & $\begin{array}{c}81 . \\
69\end{array}$ & $\begin{array}{l}74 . \\
65\end{array}$ & $\begin{array}{l}74 . \\
65\end{array}$ & $\begin{array}{l}71 . \\
83\end{array}$ & $\begin{array}{l}67 . \\
61\end{array}$ & $\begin{array}{l}63 . \\
38\end{array}$ & $\begin{array}{l}56 . \\
30\end{array}$ \\
\hline Transportatio & N/ & N/ & $\mathrm{N} /$ & N/ & $\mathrm{N} /$ & $\mathrm{N} /$ & $\mathrm{N} /$ & N/ & 1 & 0.0 & 0.0 & 0.0 & 0.0 & 0.0 & 0.0 & 0.0 \\
\hline n \& Logistics & A & A & A & A & A & A & A & A & & 0 & 0 & 0 & 0 & 0 & 0 & 0 \\
\hline Utilities & $\mathrm{N} /$ & N/ & $\mathrm{N} /$ & N/ & $\mathrm{N} /$ & $\mathrm{N} /$ & $\mathrm{N} /$ & N/ & 1 & $\begin{array}{l}10 \\
0.0\end{array}$ & $\begin{array}{l}10 \\
0.0\end{array}$ & $\begin{array}{l}10 \\
0.0\end{array} \mid$ & $\begin{array}{l}10 \\
0.0\end{array}$ & $\begin{array}{l}10 \\
0.0\end{array} \mid$ & $\begin{array}{l}10 \\
0.0\end{array}$ & 100 \\
\hline & A & A & A & A & A & A & A & A & & 0 & 0 & 0 & 0 & 0 & 0 & .00 \\
\hline \multicolumn{17}{|l|}{$\begin{array}{l}\text { Panel C: Full } \\
\text { Sample }\end{array}$} \\
\hline Total & $\begin{array}{c}16 \\
3\end{array}$ & $\begin{array}{l}82 . \\
82\end{array}$ & $\begin{array}{l}69 . \\
94\end{array}$ & $\begin{array}{l}63 . \\
19\end{array}$ & $\begin{array}{l}57 . \\
06\end{array}$ & $\begin{array}{l}53 . \\
99\end{array}$ & $\begin{array}{l}52 . \\
15\end{array}$ & $\begin{array}{l}50 . \\
28\end{array}$ & $\begin{array}{c}30 \\
6 \\
\end{array}$ & $\begin{array}{r}81 . \\
70\end{array}$ & $\begin{array}{l}76 . \\
80\end{array}$ & $\begin{array}{l}72 . \\
22\end{array}$ & $\begin{array}{l}67 . \\
65\end{array}$ & $\begin{array}{l}64 . \\
71\end{array}$ & $\begin{array}{l}61 . \\
11\end{array}$ & $\begin{array}{l}57 . \\
83\end{array}$ \\
\hline
\end{tabular}

Notes: This table shows the cumulative survival rates of IPO companies according to listing markets (ACE and Main) listed in 2002 to 2014 using the Kaplan-Meier survival analysis model for seven years of observation period. It reports the significance of the statistical difference 
between the survival rates across IPO companies' listing years and sectors using the KaplanMeier log-rank test. Panel A reports the survival rates across listing years, Panel B across sectors and Panel $\mathrm{C}$ is the full sample for each listing market (163 IPO companies for ACE Market and 306 IPO companies for Main Market). The sample starts in 2002 until 2014 for a comparative analysis between IPO companies listed in both markets because the development of the ACE market takes place in 2002 . Significant levels at $1 \%, 5 \%, 10 \%$ denote as $* * *, * *, *$, respectively.

To sum up, the results in this study should be of interest to the policymakers, issuing companies and investors as guidance to assess companies' survivability based on their listing years, sectors and markets. Since the survivability of IPO companies is of great concern to Bursa Malaysia, the findings in this study help to verify the effectiveness and frameworks of Practice Notes and Guidance Notes to elongate the survival of companies listed in the Malaysian market. Moreover, the decision to go public is the decision that requires thorough consideration by issuing companies to maximize the value of their stake, which the survivability of the companies postIPO is of great concern. As companies evolve with a systematic change, being aware of the survivability of the companies through the evaluation of listing years and sectors may provide additional insights on the probability of surviving longer post-IPO for the issuing companies. Similarly, investors concerning about companies' survivability post-IPO may be selective to IPO companies coming listed in $\mathbf{2 0 0 9}$ or avoid companies listed in the technology sector. This type of company may be unideal for their investment portfolio construction. Future researchers are suggested to further examine the contributable factors for IPO companies to survive longer postIPO using other survival analysis methods (semi-parametric or parametric).

\section{Acknowledgement}

The authors would like to acknowledge that this article is part of a research project funded by Universiti Teknologi MARA (UiTM). Project ID: 600-RMC/MYRA 5/3/LESTARI (038/2020).

\section{References}

Ahmad, I., Ismail, I., \& Shaharuddin, S. S. (2021). Predictive Role of Ex Ante Strategic Firm Characteristics for Sustainable Initial Public Offering (IPO) Survival. Sustainability, 13(14). doi:10.3390/su13148063

Ahmad, W., \& Jelic, R. (2014). Lockup Agreements and Survival of UK IPOs. Journal of Business Finance \& Accounting, 41(5-6), 717-742. doi:https://doi.org/10.1111/jbfa.12068

Ali, I., \& Hatta, Z. A. (2013) 2008 Economics Crisis in Malaysia: Implications on the Economy, Society and Safety Nets. International Journal of Business and Technopreneurship, 3(2), 261-276.

Andriansyah, A. (2017). The real effects of primary and secondary equity markets on firm performance. International Journal of Managerial Finance, 13(4), 397-418. doi:https://doi.org/10.1108/IJMF-01-2017-0006

Baluja, G. (2018). Does Size Matter for IPO Survival? Empirical Evidence from India. Vision: The Journal of Business Perspective, 22(1), 88-104. doi:https://doi.org/10.1177/0972262917750249

Baluja, G., \& Singh, B. (2016). The Survival Analysis of Initial Public Offerings in India. Journal of Advances in Management Research, 13(1). 
Bhattacharya, N., Demers, E., \& Joos, P. (2009). The Relevance of Accounting Information in a Stock Market Bubble: Evidence from Internet IPOs. Journal of Business Finance \& Accounting, 37(3-4), 291-321.

Bhattacharya, U., Borisov, A., \& Yu, X. (2015). Firm Mortality and Natal Financial Care. Journal of Financial and Quantitative Analysis, 50(1-2), 61-88. doi:10.1017/s0022109014000581.

Bursa Malaysia. (2020a). Criteria and Obligations of GN3 Companies, 1-8.

Bursa Malaysia. (2020b). Criteria and Obligations of Practice Note 17 Issuers, 1-8.

Chancharat, N., Krishnamurti, C., \& Tian, G. (2012). Board Structure and Survival of New Economy IPO Firms. Corporate Governance: An International Review, 20(2), 144-163.

Che-Yahya, N., \& Abdul-Rahim, R. (2019). Moderating Effect of Information Asymmetry on the Signalling Role of IPO Lockup Provision. Global Business Review, 20(4), 917-930. doi:https://doi.org/10.1177/0972150919844906

Che-Yahya, N., \& Matsuura, Y. (2021). Does Individual Investors' Sentiment Explain Japanese IPO Aftermarket Performance? Journal of Asian Finance, Economics and Business, 8(4), 1079-1090. doi:10.13106/jafeb.2021.vol8.no4.1079

Chou, T.-K., Cheng, J.-C., \& Chien, C.-C. (2013). How useful is Venture Capital Prestige? Evidence from IPO Survivability. Small Business Economics, 40(4), 843-863. doi:10.1007/s11187011-9389-5

Demers, E., \& Joos, P. (2007). IPO Failure Risk. Journal of Accounting Research, 45(2), 333-371.

Dziczkowski, M. (2020). Strategies for Going Public Retrieved from https://www2.deloitte.com/content/dam/Deloitte/us/Documents/risk/strategies-forgoing-public-5th-edition-update.pdf

Economic Planning Unit. (2006). Ninth Malaysian Plan 2006-2010. 1-547.

Espenlaub, S., Goyal, A., \& Mohamed, A. (2016). Impact of legal institutions on IPO survival: A global perspective. Journal of Financial Stability, 25, 98-112.

Espenlaub, S., Khurshed, A., \& Mohamed, A. (2012). IPO Survival in a Reputational Market. Journal of Business Finance \& Accounting, 39(3-4), 427-463. doi:https://doi.org/10.1111/j.1468-5957.2012.02280.x

Gémar, G., Moniche, L., \& Morales, A. J. (2016). Survival Analysis of the Spanish Hotel Industry. Tourism Management, 54, 428-438. doi:https://doi.org/10.1016/j.tourman.2015.12.012

Gregory, A., Guermat, C., \& Al-Shawawreh, F. (2010). UK IPOs: Long Run Returns, Behavioural Timing and Pseudo Timing. Journal of Business Finance \& Accounting, 37(5-6), 612-647. doi:https://doi.org/10.1111/j.1468-5957.2010.02182.x

Hamza, O., \& Kooli, M. (2010). Does Venture Capitalists Reputation Improve the Survival Profile of IPO Firms? Paper presented at the Multinational Finance Society Conference.

Helbing, P. (2019). A review on IPO withdrawal. International Review of Financial Analysis, 62, 200-208. doi:10.1016/j.irfa.2018.09.001

Hensler, D. A., Rutherford, R. C., \& Springer, T. M. (1997). The Survival of Initial Public Offerings in the Aftermarket. The Journal of Financial Research, 20(1), 93-110.

Jain, B. A., \& Kini, O. (2000). Does the Presence of Venture Capitalists Improve the Survival Profile of IPO firms? Journal of Business Finance \& Accounting, 27(9\&10), 1139-1176.

Jain, B. A., \& Kini, O. (2008). The Impact of Strategic Investment Choices on Post-Issue Operating Performance and Survival of US IPO Firms. Journal of Business Finance \& Accounting, 35(34), 459-490. 
Kooli, M., \& Meknassi, S. (2007). The Survival of U.S. IPO Issuers 1985-2005. The Journal of Wealth Management, 10(2).

Lamberto, A. P., \& Rath, S. (2010). The Survival of Initial Public Offerings in Australia. The International Journal of Business and Finance Research, 4(1), 133-147.

Peristiani, S., \& Hong, G. (2004). Pre-IPO Financial Performance and Aftermarket Survival. Current Issues in Economics and Finance, 10(2), 1-7.

Pour, E. K., \& Lasfer, M. (2013). Why do companies delist voluntarily from the stock market? Journal of Banking \& Finance, 37(12), 4850-4860. doi:10.1016/j.jbankfin.2013.08.022

Schultz, P. (1993). Unit Initial Public Offerings. Journal of Financial Economics, 34(2), 199-229.

Securities Commission Malaysia. (2020). Equity Guidelines. 1-150.

Securities Commission Malaysia. (2001). Capital Market Masterplan 1. 1-291.

Shari, W. (2019). Survival of the Malaysian Initial Public Offerings. Management Science Letters, 607-620. doi:10.5267/j.msl.2019.1.002

Suárez, F. F., \& Utterback, J. M. (1995). Dominant Designs and The Survival of Firms. Strategic Management Journal, 16, 415-430.

Vismara, S., Paleari, S., \& Ritter, J. R. (2012). Europe's Second Markets for Small Companies. European Financial Management, 18(3), 352-388. doi:https://doi.org/10.1111/j.1468036X.2012.00641.x

Wyatt, A. (2014). Is there useful information in the 'use of proceeds' disclosures in IPO prospectuses? Journal of Accounting \& Finance, 54(2), 625-667. doi:https://doi.org/10.1111/acfi.12013 